\title{
VARIATION UNDER A PSYCHOLINGUISTIC PERSPECTIVE: NUMBER AGREEMENT IN BRAZILIAN PORTUGUESE AND THE IMPACT OF SCHOOLING
}

\author{
Ana Paula S. P. Jakubów ${ }^{1 *}$ \\ Letícia M. Sicuro Corrêa ${ }^{1 * *}$ \\ ${ }^{1}$ Pontifícia Universidade Católica do Rio de Janeiro, Rio de Janeiro, RJ, Brasil
}

\begin{abstract}
This paper ${ }^{1}$ discusses the impact of schooling in the production of number agreement in Brazilian Portuguese (BP) by $6^{\text {th }}$ graders in Rio de Janeiro. Number agreement in BP can vary between: (a) redundant, the standard variety, or (b) non-redundant, non-standard forms. Such variation is influenced by speakers' socioeconomic status (SES) and educational level. Results of an elicited production experiment carried out with $6^{\text {th }}$ graders suggest influence of SES/ type of school and academic performance in language production; the effects of schooling and metalinguistic awareness are discussed. An account of language production is presented, which combines L1 and L2 models of speech production, considering the possibility of the coexistence of varieties in a single speaker to be akin to bilingualism.

Key-words: Linguistic Variation, Number Agreement, Psycholinguistics, Sociolinguistics, Schooling
\end{abstract}

\footnotetext{
"Obtained her PhD in Language Studies at the Pontifical Catholic University of Rio de Janeiro in 2018. Her research focused on language acquisition based on variable input. Her main interests are in variation as a result from language in contact within and across speakers in multilingual contexts such as bilingualism and bidialectalism and the influences of linguistic internal and external factors that regulate linguistic variation. Her email is anapaulaspj@gmail.com. ORCID: https://orcid.org/0000-0002-7832-2056.

${ }^{* *}$ Obtained a PhD in Psycholinguistics at the University of London in 1986. Since then, she has been affiliated to the Pontifical Catholic University of Rio de Janeiro (PUC-Rio), where she is now Senior Associate Professor and Research director of LAPAL (Laboratório de Psicolinguistica e Aquisição da Linguagem). Her research interests are in language processing/acquisition from a minimalist stand point, focusing on the interface information for grammar identification, processing cost, on-line syntactic computation, domain specificity and language impairment. Her email is lscorrea@puc-rio.br. ORCID: https://orcid.org/000-0002-6561-1238.
} 


\section{Introduction}

This paper is concerned with language acquisition and production based on variable input in Brazilian Portuguese (BP). Number agreement in BP can vary between: (a) redundant (a plural morpheme is present in all the agreeing elements in the sentence), the standard variety, or (b) non-redundant, non-standard forms (the plural morpheme is necessarily present in a prenominal element (the determiner, in general), but optional in the other agreeing elements). The morphophonological information concerning grammatical number is therefore somewhat inconsistent for children acquiring BP. Considering that different varieties can co-exist in a given environment, children acquiring $\mathrm{BP}$ are exposed to variable input.

The variation in number agreement in $\mathrm{BP}$ is substantially mapped by sociolinguistic investigations, both within the nominal domain and insubjectverb agreement (Brandão, 2011, 2015, 2016; Naro, 1981; Naro \& Scherre, 2015; Scherre, 1978, 1991, 1994; Scherre \& Naro, 1998, 2006; Vieira \& Brandão, 2014). These studies have consistently shown that socioeconomic status (SES) and,consequently, level of education affect the production of plural number agreement in BP, being the standard variety produced by highly educated speakers. Reconciling a psycholinguistic approach with sociolinguistic findings may, therefore, enhance our understanding on how variable input is represented and processed. In particular, the possibility of a sort of bilingual condition is considered, given formal instruction and the progressive contact with written BP at school.

This paper is divided as follows: in the next section, the variable phenomenon of number agreement in BP is presented; in the third section, an account of language acquisition based on variable input is provided; the forth section reports an elicited production experiment carried out with $6^{\text {th }}$ graders; then, the results are discussed in relation to L1 and L2 models of speech production, which are combined in an account of the language and processing abilities acquired under variable input. The impact of the present approach for language teaching is pointed out, followed by the final remarks.

\section{Variation of number agreement in Brazilian Portuguese}

BP presents variable plural number agreement, unlike European Portuguese (EP) (Brandão, 2011, 2015, 2016; Naro, 1981; Naro \& Scherre, 2015; Scherre, 1978, 1991, 1994; Scherre \& Naro, 1998, 2006; Vieira \& Brandão, 2014). Sociolinguistic studies propose that the variable phenomenon is influenced by SES and level of schooling: "The popular variants tend to occur more frequently in the speech of the lower socio-economic levels, while the standard variants are found more frequently in the speech of the higher socio-economic levels, on radio and television" (Naro, 1981). There are two possible morphophonological means of expressing number agreement in BP: a) redundant expression (see example 
1), the standard variety, similar to EP; and b) non-redundant agreement, nonstandard forms (see examples 2 - 6):

(1) Redundant (Scherre \& Naro, 2006):

a-scoisa-s tão muito car-a-s, né

ART.DEF.FEM-PL thing.FEM-PL be.3.PRS.SG very expensive-FEM-PL right 'Things are very expensive, right?'

(2) Non-redundant nominal agreement (Scherre \& Naro, 2006):

Essa-sestrada-s nova- $\varnothing$

DEM.FEM-PL road.FEM-PL new.FEM-SG

'These new roads'

(3) Non-redundant nominal and subject-verb agreement: (Scherre \& Naro, 2006):

Esse-s cara- $\varnothing \quad$ hoje sóqué-ø

DEM.MASC-PL guy.MASC-SG today only want.3.PRS-SG

curtímesmo, né.

enjoy-INF indeed right

'Nowadays, these guys just want to have some fun, you see'

(4) Non-redundant nominal agreement with possessives (Scherre, 1978):

$A-\varnothing \quad$ minha-s três primeira-stia-s

ART.DEF.FEM-SG POSS.1.FEM-PL threefirst.FEM-PL aunt.FEM-PL

'My first three aunts'

(5) Non-redundant subject-verb agreement (Almeida, 2010):

A-sdúvida-s faz parte...

ART.DEF.FEM-PL doubt.FEM-PL make.3.SG.PRS part

'(The) Doubts are part of the process...'

A-spessoa-s não toma-ø atitude

ART.DEF.FEM-PL people.FEM-PL not take-SG attitude

'(The) People don't have initiative...'

A-satitude-sruin-safeta- $\varnothing . .$.

ART.DEF.FEM-PL attitude.FEM-PL bad-PL affect.3.PRS-SG

'(The) Negative acts affect...'

(6) Non-redundant nominal, subject-verb and predicative agreement (Scherre\&Naro, 2006):

que a-s coisa-ø tá car-a- ø,

COMP ART.DEF.FEM-PL thing.FEM-SG be.3.PRS.SG expensive-FEM-SG

'because things are expensive'

The possibility of optional number marking in all elements of an agreement relation by the determiner/prenominal elements can be viewed as grammatical 
knowledge internalized by BP speakers. ${ }^{2}$ Brandão (2013) proposes that the rule of number agreement in BP is semicategorical for speakers at a high socioeconomic level and variable for speakers at a low socioeconomic level, while in EP, the rule is categorical. Considering the social factors that influence variation, she completes: "in EP, the input for the agreement is robust, regardless of the education level of the individual. In BP, where the rule is variable, the input is differentiated depending on the socio-economic-cultural class to which the child's family belongs [...]" (Brandão, 2013).Considering the coexistence of different varieties of number agreement in BP, children exposed to variable input are faced with an acquisition challenge. How would they represent variation? In the next section, a procedural language acquisition model is presented in order to account for the acquisition of variation.

\section{An account of acquisition based on variable input}

Studies on language acquisition based on variable input in BP are very scarce, despite innumerous investigations by sociolinguists (see Gomes et al., 2011). In this paper, it is assumed that in early language acquisition, children identify distributional and morphophonological patterns in the input, which are taken as cues for grammatically relevant distinctions (Corrêa, 2009). By 9-13 months of age, children are sensitive to the pattern of functional items in the language, which enables them to compose two grammatically relevant categories in the lexicon (functional words and their complement (Shafer, Shucard, Shucard, \& Gerken, 1998; Shi, Werker, \& Cutler, 2003)). Brazilian infants are sensitive to morphophonological changes in verb affixes by the age of 10 months(Bagetti \& Corrêa, 2009). There is evidence that they are sensitive to the form of determiners by the age of 14 months (Corrêa \& Name, 2003) and by the age of 22 months, children acquiring BP and EP have represented the plural morphology in the determiner (Castro \& Ferrari-Neto, 2007; Corrêa, Augusto, \& Ferrari-Neto, 2006). Gradually, the formal features of the functional items are specified, as the semantic distinctions they convey are represented in the mental lexicon. Based on such amodel of language acquisition, given variable input, children are faced with a challenge: even though number is specified as a formal feature in the lexicon and its morphophonological expression is consistent in the determiner (or pre-nominal elements), the expression of number agreement is variable in the noun and other agreeing elements.

Jakubów and Corrêa (2018) investigated children's variable production of number agreement in BP by comparing the speech production of preschoolers (age range: 3;8 - 6;3, mean age: 5,5) from a private and a public school in Rio de Janeiro city. The type of school was taken as a social variable given that municipal schools tend to concentrate students from low SES families, whereas private schools concentrate students from middle-to-high SES families or communities (Alves, Soares, \& Xavier, 2014; Brasil, 2017b). The results of an elicited production experiment task show that the standard variety predominates in both groups. 
However, preschoolers from the private school produce the standard variety of number agreement more frequently than preschoolers from the public school.

Extending Corrêa's (2009) procedural account of language acquisition and the idea of underspecification proposed by Adger\& Smith's (2010), Jakubów and Corrêa (2018) suggested that exposure to variable input of number agreement in BP leads to an underspecified representation of the features pertaining to the morphophonological expression of number agreement (either redundant - in all the agreeing elements; or non-redundant - only in D (or in a prenominal element in some cases)). Notice, however, that Jakubów and Corrêa (2018) adopted the term underspecification as presented in Rooryck (1994), in which a feature has open values, that is, it can assume one value or another in a chameleon-like fashion. Moreover, underspecification in their account is not related to syntactic features, but to the morphophonological features pertaining toredundancy in number agreement in BP.

Assuming Levelt's speech production model (1989), it can be argued that children access the underspecified representation of such a morphophonological feature in the lexicon during the morphophonological encoding of a referential expression. Hence, during this process, two possibilities would be available: a) redundant, that is, plural morpheme in all the agreeing elements, or b) nonredundant, meaning plural morpheme necessarily expressed in $\mathrm{D} /$ prenominal elements and optional plural morpheme in other agreeing elements. The possibility that eventually comes out is likely to be affected by language external factors such as frequency (Levelt, 1999).

Among recent endeavours to reconcile psycho and sociolinguistic approaches in the study of language acquisition based on variable input, Molina (2018) investigatedthe spontaneous production of variable $3^{\text {rd }}$ person subject-verb number agreement by BP-speaking children and their caregivers. She compared corpora obtained from high SES families living in an urban area of Minas Gerais and low SES families living in the rural area of the state. The analysis suggests that Brazilian children identify the obligatory marking of number in at least one element of the DP since early ages. However, children from a low SES environment produce less redundant number marking than those from a high SES environment, in accordance with sociolinguistic findings. Additionally, Molina detects variation even in the speech of caregivers from a high SES environment and a high educational level. Another part of Molina's investigation focuses on the comprehension of subject-verb agreement. In an offline picture-selection task, type of subject (null or lexical), number agreement in the verb (redundant or non-redundant) and verb tense (present or past) were the within-subject independent variables. Additionally, two group variables were manipulated: age (5 and 6-year-olds) and SES (private and public school). Overall, 6-year-olds from the private school presented more matching responses than the public school group in the present tense condition. Regarding the past tense, plural verb forms and lexical subject prompted more matching responses. Both group variables gave 
rise to significant differences, with more matching responses in the 6-yearold group and in the private school group.

The psycholinguistic investigations reported here corroborate sociolinguistic findings insofar as both Jakubów and Corrêa (2018) and Molina (2018) found variation influenced by SES in child language development around 5 and 6 years of age. In this paper, the aim is to characterize the effects of schooling in children's representation of variation, considering formal exposure to the standard variety of number agreement in BP.

\section{Elicited production experiment}

This investigation aimed to verify the impact of schooling on children's production of number agreement in $\mathrm{BP}^{3}{ }^{3}$ The research questions were: (i) does schooling affect the production of number agreement in BP?; (ii) to which extent can the acquisition of the morphophonological expression of number agreement in BP be compared to a gradient continuum of bilingualism (Grohmann, 2014)?

The elicited production task and the experimental design in Jakubów and Corrêa (2018)were used in the present study with BP-speaking $6^{\text {th }}$ graders, with some adaptations to the older children in the procedure. The aims of the present experiment were to verify whether:

(i) type of school, taken as a social variable, plays any role on the production of number agreement during schooling years;

(ii) literacy and schooling affect the production of redundant forms of number agreement, considering the exposure to the written modality of $\mathrm{BP}$ and the metalinguistic awareness that may be achieved due to the formal and systematic teaching of the standard variety.

\subsection{Experimental Design}

As in the previous study with young children, the participants were asked to retell what a robot had told them. The robot produced sentences that varied according to possible morphophonological expressions of redundancy in number agreement. The independent variables were: 1. Redundancy in Plural Number Agreement (within-subject; four levels) and 2. Type of School (between-subject; 2 levels), giving rise to 4 conditions presented to each group:

Table 1: Experimental conditions

\begin{tabular}{ll}
\hline Conditions & Examples of Stimuli \\
\hline 1. DP red & O-scachorro-sencontr-aramo leão \\
TP red & ART.DEF.MASC-PL dog.MASC-PL find-3.PST.PL the lion \\
& 'The dogs found the lion' \\
\hline
\end{tabular}




\begin{tabular}{ll}
\hline $\begin{array}{l}\text { 2. DP red } \\
\text { TP n-red }\end{array}$ & $\begin{array}{l}\text { O-scachorro-sencontr-ou o leão } \\
\text { ART.DEF.MASC-PL dog.MASC-PL find-3.PST.SG the lion } \\
\text { 'The dogs found the lion' }\end{array}$ \\
\hline $\begin{array}{c}\text { 3. DP n-red } \\
\text { TP red }\end{array}$ & $\begin{array}{l}\text { O-s cachorro- } \varnothing \text { encontr-aramo leão } \\
\text { ART.DEF.MASC-PL dog.MASC-SG found-3.PST.PL the lion } \\
\text { 'The dogs found the lion' }\end{array}$ \\
$\begin{array}{l}\text { 4. DP n-red } \\
\text { TP n-red }\end{array}$ & ART.DEF.MASC-PL dog.MASC-SG found-3.PST.SG the lion \\
\hline
\end{tabular}

The dependent variable 1 was the number of matching responses corresponding to the form of the stimuli provided by the robot. The dependent variable 2 was the number of responses matching the standard variety (condition 1 ).

\subsection{Participants}

The participants were seventy-seven $6^{\text {th }}$ graders from a private and a public school in Rio de Janeiro grouped according to the type of school they attended: a) Priv (private school - middle-high SES/educational level) and b) Pub (public school- middle-low SES/educational level) ${ }^{4}$. The groups were arranged as follows:

Table 2: Groups of $6^{\text {th }}$ graders as a function of Type of School

\begin{tabular}{llllll}
\hline Type of school & $\mathbf{n}$ & girls & boys & Age range & Mean age \\
\hline Priv & 25 & 14 & 11 & $10 ; 11-12 ; 11$ & $11 ; 1$ \\
\hline Pub & 52 & 29 & 23 & $11 ; 1-14 ; 6$ & $12 ; 6$ \\
\hline
\end{tabular}

\subsection{Material}

In the linguistic stimuli, the type of subject was controlled: plural, definite, masculine animated subjects, with determiners necessarily marked for plural. The type of verb was also controlled: transitive and action verbs in the simple past tense. Animacy and gender were counterbalanced in the verbal complement. The length of the verbal stimuli (the sentences produced by the robot) was $8-11$ syllables. Each participant was exposed to 16 test-sentences in a Latin-square design (4 different lists with 4 stimuli per condition). An animated character with robot-or-alien-like characteristics was created and introduced as someone who came from a distant place, where people spoke in an unusual way. The verbal material was recorded and edited in the software Audacity for pitch alterations in order for the recorded voice to sound different from the experimenter's voice and compatible with the character.

The apparatus consisted of a DELLInspiron, i3 processor laptop, a Sony MP3 player-recorder and/or in a Panasonic RR-US511 recorder. 


\subsection{Procedure}

Participants were presented to a sort of game in which they had to remember what the robot had told them after performing a mathematical task. After listening to what the robot had said, they were asked to calculate a simple arithmetic sum, to tell its results and only afterwards they would have to recall the information provided by the robot. The following steps illustrate the elicitation of the responses: 1) play the verbal stimulus; 2) stop it; 3) experimenter asks: 'how much is ... (5+2, for instance)?'4) participant's answers; 5) experimenter gives the command: 'Ok, now tell me what Bob (the animated character on the laptop) has told you..' Such a procedure was intended to swift the participant's attention from the memorization of the sentence produced by the robot to the resolution of the math calculation. It was assumed that the sentence produced would be newly formulated according to the participant's grammar. In other words, the participants would not simply repeat the sentences but access the means of expressing number agreement in their language variety.

The participants performed the task individually, under consent, in an isolated room in the school. At the end of the task, the experimenter asked whether they thought Bob really spoke in an unusual way, in order to have access to the degree of their metalinguistic awareness concerning number agreement. The sentences produced were recorded and transcribed. Whenever the school did not allow recording, the responses were written down. If children changed words, saying cachorros ('dogs') instead of gatos ('cats') as provided in the stimuli, the response would be considered as matching the stimuli, since the plural morpheme was produced. The task lasted around 10 minutes.

\subsection{Results per Type of School}

\subsubsection{Dependent Variable 1: Matching responses}

A 2-way ANOVA (design 4 X 2), in which Redundancy in Number Agreement is a within-subject factor (4 levels) and Type of School is a betweensubject factor (2 levels), showed that, for the responses that matched the stimuli provided, there was a significant main effect of Redundancy $(\mathrm{F}(1,75)=117$, 829; $\mathrm{p}<.0001 ; \mathrm{C} 1: M=3,30, S D=1,2 ; \mathrm{C} 2: M=0,62, S D=1 ; \mathrm{C} 3: M=0,88, S D$ $=1,3 ; \mathrm{C} 4: M=0,7, S D=1,1)$ : 
Graph 1: Mean matching responses as a function of Redundancy in Number Agreement
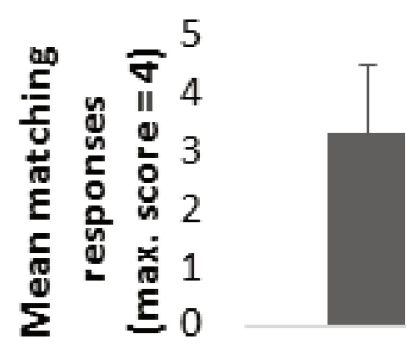

\section{DP red 2. DP red TP red TP n-red}

3. DP n-red

4. DP n-red TP red TP n-red

Additionally, there was an effect of Type of School $(\mathrm{F}(1,75)=11,195 ; \mathrm{p}=.001$; Priv: $M=$ $1,08, S D=0,3$; Pub: $M=1,52, S D=1,3$ ):

Graph 2: Mean matching responses as a function of Type of School
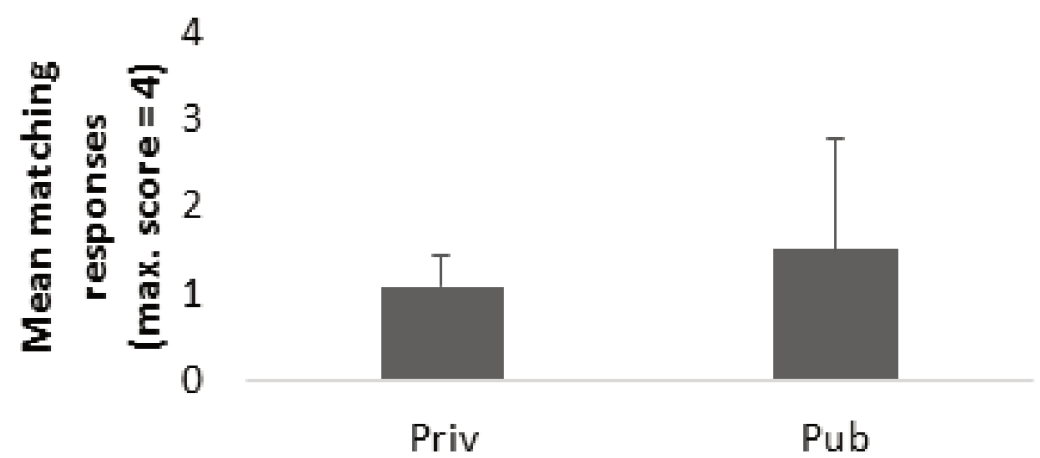

There was also an effect of interaction between Redundancy and Type of School (F $(1,75)$ $=14,488 ; \mathrm{p}<.0001 ;$ Priv C1: $M=3,96, S D=0,2 ; \mathrm{C} 2: M=0,12, S D=0,4 ; \mathrm{C} 3: M=0,16, S D$ $=0,5 ; \mathrm{C} 4: M=0,08, S D=0,3 ; \mathrm{Pub} \mathrm{C} 1: M=2,98, S D=1 ; \mathrm{C} 2: M=0,87, S D=1,2 ; \mathrm{C} 3: M=$ $1,23, S D=1 ; C 4: M=1, S D=1,1)$ :

Graph 3: Mean matching responses as a function of Redundancy in Number Agreement per Type of School
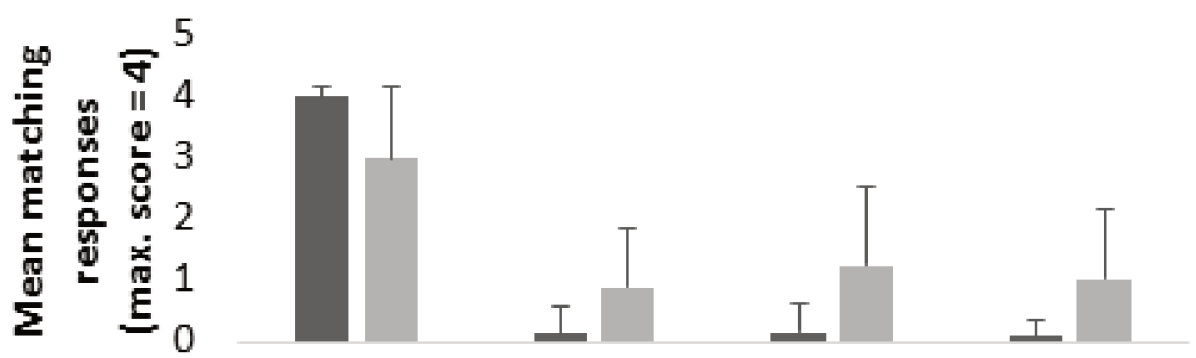

Priv
1. DP red
2. DP red
3. DP n-red
4. DP n-red
TP red
TP n-red
TP red
TP n-red

Altogether, the results of matching responses show that both groups preferred the standard variety. However, they differed in the production of non-standard forms: Pub exhibits higher means for non-standard conditions than Priv. 


\subsubsection{Dependent Variable 2: Standard responses}

Regarding the standard responses provided in each condition, the data were analyzed by means of a 2-way ANOVA (design 4 X 2), in which Redundancy is a within-subject factor (4 levels) and Type of School is a between-subject factor (2 levels). There was a significant main effect of Redundancy $(\mathrm{F}(1,75)=49,060 ; \mathrm{p}$ $<.0001 ; \mathrm{C} 1: M=3,31, S D=1,1 ; \mathrm{C} 2: M=2,18, S D=1,6 ; \mathrm{C} 3: M=2,77, S D=1,5$; C4: $M=1,96, S D=1,7)$ :

Graph 4: Mean standard responses as a function of Redundancy in Number Agreement
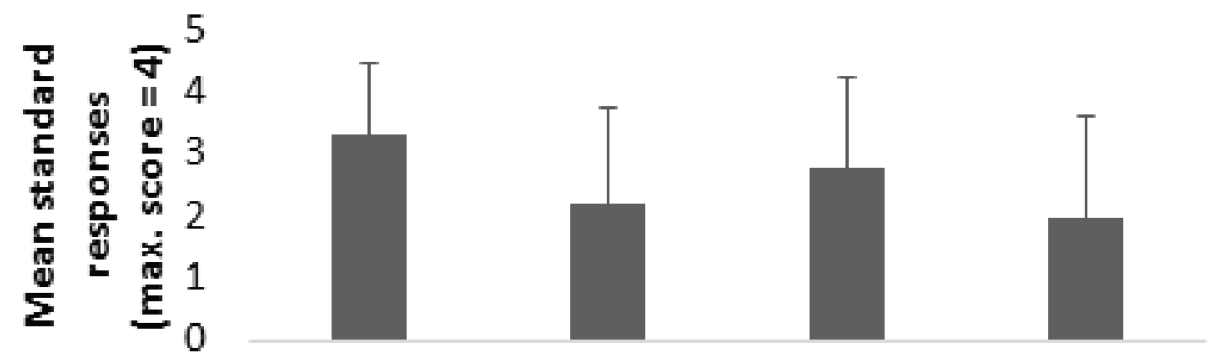

\section{DP red \\ 2. DP red \\ 3. DP n-red \\ 4. DP n-red \\ TP red \\ TP n-red \\ TP red \\ TP n-red}

Furthermore, there was an effect of Type of $\operatorname{School}(\mathrm{F}(1,75)=37,373 ; \mathrm{p}<.0001$; Priv: $M$ $=3,62, S D=0,7$; Pub: $M=2,05, S D=1,4)$ :

Graph 5: Mean standard responses as a function of Type of School
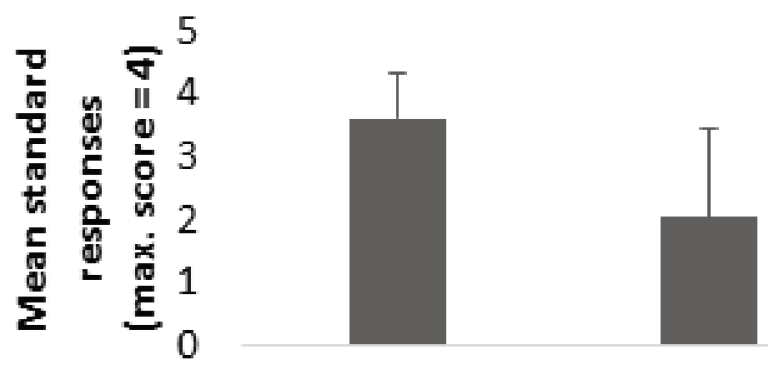

Priv

Pub

There was also an effect of interaction between Redundancy and Type of School $(\mathrm{F}(1,75)$ $=15,306 ; \mathrm{p}<.0001$; Priv $\mathrm{C} 1: M=3,96, S D=0,2 ; \mathrm{C} 2: M=3,36, S D=1 ; \mathrm{C} 3: M=3,76, S D$ $=0,5 ; \mathrm{C} 4: M=3,4, S D=1 ; \mathrm{Pub} C 1: M=3, S D=1,3 ; \mathrm{C} 2: M=1,62, S D=1,5 ; \mathrm{C} 3: M=2,29$, $S D=1,5 ; C 4: M=1,27, S D=1,5)$ : 
Graph 6: Mean standard responses as a function of Redundancy in Number Agreement per Type of School

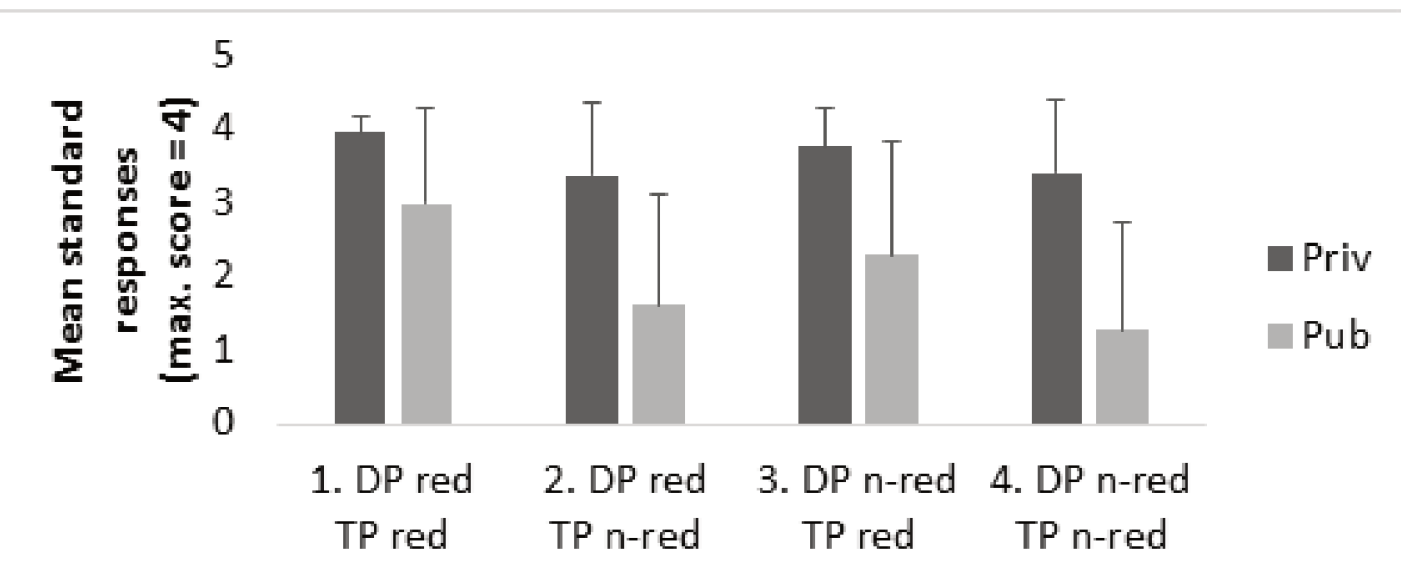

Overall, the $6^{\text {th }}$ graders' results show that the differences between groups are attenuated during schooling years. Literacy seems to enhance $6^{\text {th }}$ graders' awareness of the differences between varieties. Given the tracking school system adopted by the public school at stake, in which students are grouped according to their overall academic performance, we decided to run another analysis within the Pub group in order to verify whether this factor influences the production of number agreement in BP.

\subsection{Results per Academic Performance in the public school}

The data of the public school $6^{\text {th }}$ graders were further analysed by contrasting two groups as above-average academic performance (Pub A) and below-average academic performance (Pub B), as informed by the school:

Table 3: Groups of Pub $6^{\text {th }}$ graders as a function of Academic Performance

\begin{tabular}{llllll}
\hline Academic Performance & n & girls & boys & Age range & Mean age \\
Pub A & 25 & 17 & 8 & $11 ; 3-14 ; 6$ & 12 \\
Pub B & 27 & 12 & 15 & $11 ; 1-14 ; 5$ & $12 ; 6$ \\
\hline
\end{tabular}

The data were analysed by means of a 2-way ANOVA (design 4 X 2) in which Redundancy is a within-subject factor (4 levels) and Academic Performance is a between-subject factor (2 levels).

\subsubsection{Dependent Variable 1: Matching responses}

An effect of Redundancy was attested (F $(1,50)=35,571 ; \mathrm{p}<.0001 ; \mathrm{Cl}: M=$ 2,98, $S D=1,3 ; \mathrm{C} 2: M=0,87, S D=1 ; \mathrm{C} 3: M=1,23, S D=1,4 ; \mathrm{C} 4: M=1, S D=1,3)$ : 
Graph 7: Mean matching responses as a function of Redundancy in Number Agreement
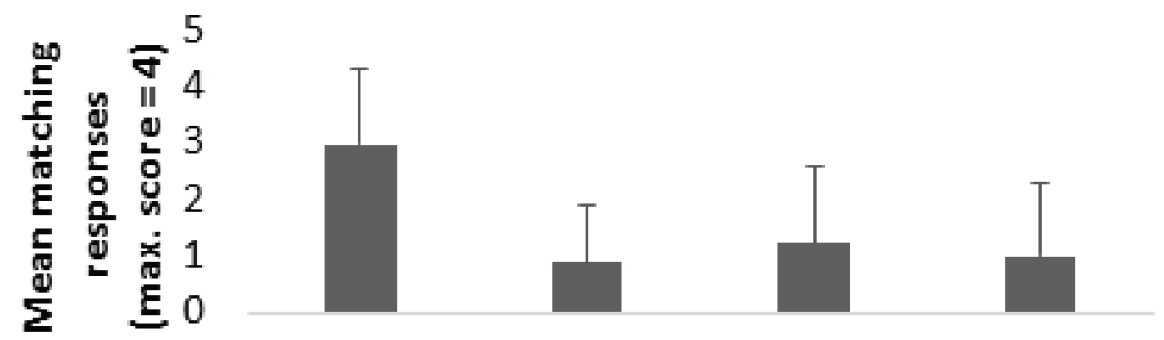

\begin{tabular}{|c|c|}
\hline 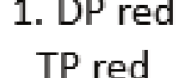 & $\begin{array}{l}\text { 2. DP red } \\
\text { TP n-red }\end{array}$ \\
\hline
\end{tabular}

An effect of Academic Performance was also obtained ( F $(1,50)=19,761 ; \mathrm{p}<$ .0001 ; Pub A: $M=1,17, S D=0,9$; Pub B: $M=1,84, S D=1,3$ ):

Graph 8: Mean matching responses as a function of Academic Performance

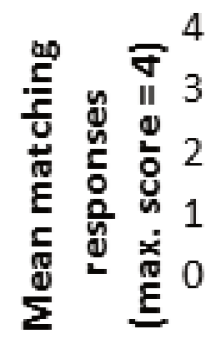

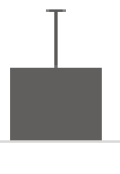

Pub A

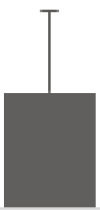

Pub B

\section{Academic Performance}

An effect of interaction between Redundancy and Academic Performancewas attested (F $(1,50)=15,35 ; \mathrm{p}<.0001$; Pub A C1: $M=3,36, S D=1,2 ; \mathrm{C} 2: M=0,6$, $S D=0,9 ; \mathrm{C} 3: M=0,48, S D=1 ; \mathrm{C} 4: M=0,24, S D=0,5 ; \mathrm{Pub} \mathrm{B} \mathrm{Cl}: M=2,63, S D=$ 1,4; $\mathrm{C} 2: M=1,11, S D=1,2 ; \mathrm{C} 3: M=1,93, S D=1,4 ; \mathrm{C} 4: M=1,7, S D=1,4)$ :

Graph 9: Mean matching responses as a function of Redundancy in Number Agreement per Academic Performance

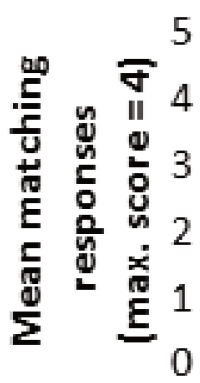

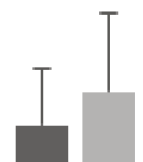

1. DP red TP red
2. DP red TP n-red

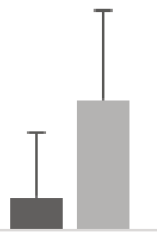

3. DP n-red TP red
Pub A Pub B

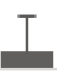

4. DP n-red TP n-red 
Overall, the results show that the standard condition (DP red/ TP red) is the most reproduced one in both groups. However, Pub B reproduces non-standard forms more often than Pub A.

\subsubsection{Dependent Variable 2: Standard responses}

A 2-way ANOVA (design 4 X 2), in which Redundancy is a within-subject factor (4 levels) and Academic Performance is a between-subject factor (2 levels), showed a main effect of Redundancy (F $(1,50)=80,728 ; \mathrm{p}<.0001 ; \mathrm{Cl}: M=3, S D$ $=1,3 ; \mathrm{C} 2: M=1,62, S D=1,5 ; \mathrm{C} 3: M=2,29, S D=1,5 ; \mathrm{C} 4: M=1,27, S D=1,5)$ :

Graph 10: Mean standard responses as a function of Redundancy in Number Agreement

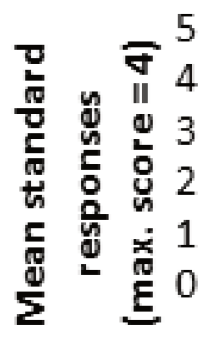

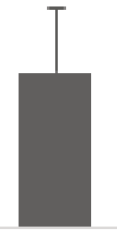

1. DP red TP red

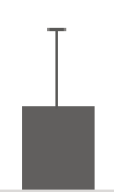

2. DP red TP n-red

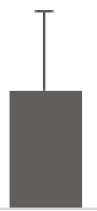

3. DP n-red 4. DP n-red TP red TP n-red

A main effect of Academic Performance was also attested (F $(1,50)=17,877$; $\mathrm{p}<.0001$; Pub A: $M=2,69, S D=1,4$; Pub B: $M=1,44, S D=1,2)$;

Graph 11: Mean standard responses as a function of Academic Performance

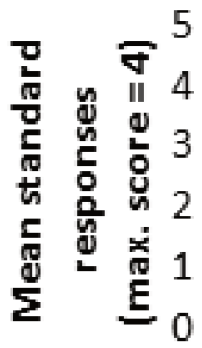

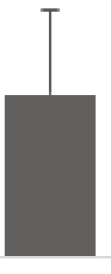

Pub A

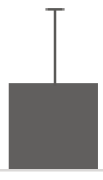

Pub B

There was no effect of interaction between Redundancy and Academic Performance $(\mathrm{F}(1,50)=3,272 ; \mathrm{p}=130 ;$ Pub A C1: $M=3,4, S D=1 ; \mathrm{C} 2: M=2,44$, $S D=1,6 ; \mathrm{C} 3: M=2,92, S D=1,3 ; \mathrm{C} 4: M=2, S D=1,6 ; \mathrm{Pub} \mathrm{B} C 1: M=2,63, S D=$ 1,4; $\mathrm{C} 2: M=0,85, S D=1 ; \mathrm{C} 3: M=1,7, S D=1,5 ; \mathrm{C} 4: M=0,59, S D=1$ ).

In general, standard responses are most frequently provided in condition 1 (DP red/ TP red), which is the standard variety, and in condition 3 (DP n-red/ TP red), in which the verb is in the plural form. Overall, these results show that academic performance during schooling years enhances the production of the 
standard variety and that the form of the verb in the input has an impact on the activation of the morphophonological form of agreement.

\subsubsection{Awareness of varieties}

The table below informs the distribution of variety awareness concerning the lack of plural morpheme expressed redundantly in the stimuli, when participants were asked if the robot presented in the experiment spoke in an unusual way:

Table4: $6^{\text {th }}$ graders - Distribution (\%) of children as a function of Social Group and Morphological Awareness

\begin{tabular}{ll}
\hline $\begin{array}{l}\text { Social } \\
\text { Group }\end{array}$ & Morphological Awareness \\
\hline Priv (25) & 84 \\
Pub A (25) & 72 \\
Pub B (27) & 29 \\
\hline
\end{tabular}

The table below shows the responses provided by $6^{\text {th }}$ graders in each experimental condition:

Table 5: Distribution (\%) of responses per condition and type of school/ academic performance $-6^{\text {th }}$ graders

\begin{tabular}{|c|c|c|c|c|c|c|c|c|c|c|c|c|c|c|c|c|c|c|c|c|c|c|}
\hline \multirow[b]{3}{*}{$\begin{array}{l}\text { Type of } \\
\text { School/ } \\
\text { Academic } \\
\text { Performance }\end{array}$} & \multicolumn{22}{|c|}{ Types of responses } \\
\hline & \multicolumn{3}{|c|}{$\begin{array}{l}\text { DP red } \\
\text { TP red }\end{array}$} & \multicolumn{3}{|c|}{$\begin{array}{l}\text { DP red } \\
\text { TP n-red }\end{array}$} & \multicolumn{3}{|c|}{$\begin{array}{l}\text { DP n-red } \\
\text { TP red }\end{array}$} & \multicolumn{3}{|c|}{$\begin{array}{l}\text { DP n-red } \\
\text { TP n-red }\end{array}$} & \multicolumn{3}{|c|}{ Singular } & \multicolumn{3}{|c|}{ No D } & \multicolumn{3}{|c|}{$\begin{array}{l}\text { Ungram- } \\
\text { matical }\end{array}$} & \multirow[b]{2}{*}{$\begin{array}{l}\text { Total valid } \\
\text { responses }\end{array}$} \\
\hline & 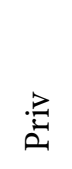 & $\begin{array}{l}4 \\
\hat{Z} \\
2\end{array}$ & $\begin{array}{l}n \\
\vec{Z}\end{array}$ & $引$ & $\begin{array}{l}\varangle \\
\vec{Z} \\
0\end{array}$ & $\begin{array}{l}n \\
\hat{Z}\end{array}$ & 离 & $\begin{array}{l}\varangle \\
\hat{Z} \\
2\end{array}$ & $\begin{array}{l}n \\
\hat{Z}\end{array}$ & : & $\begin{array}{l}4 \\
\hat{2}\end{array}$ & $\begin{array}{l}n \\
2\end{array}$ & $\overrightarrow{=}$ & $\begin{array}{l}1 \\
0 \\
2\end{array}$ & $\begin{array}{l}n \\
2 \\
2\end{array}$ & $\stackrel{2}{2}$ & $\begin{array}{l}\varangle \\
\hat{2}\end{array}$ & $\begin{array}{l}n \\
\hat{2}\end{array}$ & 竞 & $\begin{array}{l}\varangle \\
\hat{2}\end{array}$ & $\begin{array}{l}n \\
2\end{array}$ & \\
\hline \multicolumn{23}{|l|}{ Condition } \\
\hline 1 & 27 & 23 & 32 & 0 & 1 & 1 & 0 & 2 & 10 & 0 & 0 & 1 & 0 & 3 & 1 & 0 & 0 & 0 & 0 & 0 & 0 & 308 \\
\hline 2 & 27 & 20 & 7 & 5 & 10 & 1 & 1 & 2 & 5 & 1 & 2 & 10 & 2 & 4 & 3 & 0 & 0 & 0 & 0 & 0 & 0 & 308 \\
\hline 3 & 31 & 24 & 15 & 0 & 0 & 0 & 4 & 17 & 1 & 0 & 0 & 1 & 0 & 0 & 0 & 0 & 0 & 0 & 0 & 4 & 2 & 308 \\
\hline 4 & 28 & 16 & 5 & 0 & 6 & 8 & 2 & 3 & 3 & 2 & 15 & 1 & 2 & 5 & 3 & 0 & 0 & 0 & 0 & 0 & 1 & 308 \\
\hline
\end{tabular}

Condition $1=\mathrm{DP}$ red $/ \mathrm{TP}$ red Condition 2 = DP red/ TP n-red Matching responses in bold.

Condition 3 = DP n-red $/$ TP red

Condition 4 = DP n-red/ TP n-red

These results point to the fact that academic performance actually boosts sensitivity to the distinctions between varieties regarding standard and nonstandard forms of number agreement in BP. Morphological awareness is a byproduct of schooling and formal exposure to the standard variety of Portuguese. The production of written essays in the standard variety and the exposure to reading activities and grammar classes during school years are likely to affect the 
production of number agreement in the standard form in BP. The data suggest nevertheless that, even within the same school, students' responses are subject to a great range of variability regarding redundancy in number agreement. Moreover, morphological awareness does not entail standard-variety-only production. Within Priv, 66,6\% of participants who were aware of the lack of plural produced standard-only forms. For Pub A, the percentage of standard-only production drops to $27,7 \%$ for those $6^{\text {th }}$ graders who were aware of the lack of the plural morpheme. For Pub B, this percentage drops even more, to $12,5 \%$. An interesting fact is that one participant in Pub B exhibited morphological awareness ('he omits the plural') but did not produce any standard responses.

Morphological awareness may facilitate code-switching between varieties as a function of contextual factors during speech production. Perceiving and mapping contextual information as well as being able to choose the variety to be produced is part of the speaker's sociolinguistic competence. This type of competence is not the focus of monolingual language production models (see Levelt, 1989, 1999). However, sociolinguistic competence is well-described in L2 models of language production which considers the sociolinguistic competence as part of a broader component of communicative competence (Bachman \& Palmer, 1996; Faerch \& Kasper, 1983; see also Canale \& Swain, 1980). In the next section, some considerations are provided on how to bridge the gap between L1 and L2 models of language production.

\section{How can L2 models of speech production and language proficiency inform $\mathrm{L} 1$ development? The case of variable number agreement in BP}

Awareness of varieties in speech production is necessarily related to a set of communicative skills speakers must develop to build a communicative goal. In Levelt's (1989) L1 processing model, the communicative goal is mentioned as part of the macroplanning in the conceptualizer component.

In his model, there are two moments within the conceptualizer component: 1) macroplanning, when a communicative goal is set and 2) microplanning, when propositional information is established. Levelt suggests access to declarative and procedural knowledge in the conceptualizer, being the former related to processes of message-generating and monitoring by the working memory, and the latter, a propositional type of knowledge in long term memory, related to discourse and situational knowledge. In Levelt's model, it is possible to posit the choice of a variety during message generation within the conceptualizer, in which the situation knowledge is mapped. This is the only component of the model that allows for social factors to be considered prior to the lexical access that leads to grammatical encoding in speech production.

In our experimental results, Priv $6^{\text {th }}$ graders and most Pub $6^{\text {th }} \mathrm{A}$ assessed the information presented by the robot during the task and were able to correct the sentences by producing them in the standard variety. Their response to the question of whether Bob was speaking in an unusual way showed explicitly that they processed and analysed non-standard sentences as deviant. As commented 
before, awareness of the presence of morphemes does not necessarily guarantee standard-only production. Assuming a theoretical model of communicative competence in second language acquisition, as proposed by Canale and Swain (1980), the mismatch between awareness and production may be explained by the set of competences required to achieve communicative competence. According to Canale and Swain (1980), communicative competence is divided into three major components (Canale \& Swain, 1980, p. 29):

(1) Grammatical competence: includes lexical items, rules of morphology, syntax, sentence-grammar semantics and phonology;

(2) Sociolinguistic competence: includes sociocultural rules of use and rules of discourse;

(3) Strategic competence: includes verbal and non-verbal strategies used to compensate breakdowns in communication.

Even though Canale and Swain neither develop a speech production model nor the inner structure of each component, they suggest that the sociolinguistic competence component is supposed to assure that utterances are produced and understood appropriately according to the sociocultural context. It depends on factors such as topic, role of participants, setting, norms of interaction, attitude, register and style (Canale \& Swain, 1980, p. 29). This component is, then, relevant for the type of sociolinguistic variation found in number agreement in BP. Other L2 researchers propose that these components are actually interdependent and that the strategic component has access to the other components and compiles information in order to provide a solution to a particular communicative problem.

Færch and Kasper (1983) L2/ interlanguage speech production model focuses on the strategic competence of the L2 speaker and the strategies the learner uses to compensate gaps in communication during utterance planning or execution. These strategies are connected to problem-solving and can be of two major types: reduction and achievement. The former is an attempt of the learner to communicate using a reduced system "to avoid producing non-fluent or incorrect utterances" (Færch \& Kasper, 1983, p. 38) and the latter is related to the expansion of communicative resources to overcome some communicative problem.

Færch and Kasper's (1983, p. 25) model is composed of two major components: a planning phase, which includes goals, planning process/ plan, and an execution phase, which includes plan, execution process and action. Feedback and monitoring are assumed for all the phases. According to this L2/ interlanguage model, goal and planning are connected in the sense that the communicative goal leads to situational assessment; however, they highlight: "In L1 communication, planning processes are normally subconscious and highly automatic, a fact which may explain the occurrence of transfer from L1 in communication performed by insufficiently automatized L2." (Færch \& Kasper, 1983, p. 25).

Bachman and Palmer (1996) expand the notion of strategic competence in L2 presented by Færch and Kasper (1983) and breakdown the notion of language 
ability into: language knowledge and strategic competence. The latter is divided into goal setting, assessment and planning. The assessment component is responsible to check the appropriateness of responses and the characteristics of language use, linking language knowledge to topical knowledge and the situational context. This component is, thus, responsible for identifying the information pertaining to linguistic variety or dialect, and the linguistic system that best fits the communicative goal; for verifying shared knowledge with the interlocutor; and for assessing the achievement of the communicative goal (Bachman, 2003 [1990]).

In their language proficiency model in L2, Bachman (2003 [1990]) and Bachman and Palmer (1996) provide a series of components, before the proper linguistic formulation responsible for the engagement of the speaker in the communicative situation. Considering Bachman and Palmer's perspective in L2 and the $6^{\text {th }}$ graders' results presented, it is possible to suggest that:

- Priv $6^{\text {th }}$ graders and most of Pub $6^{\text {th }}$ graders in group A are able to assess the situational context, including sociolinguistic and grammaticalknowledge pertaining to the standard variety when assessing the linguistic variety spoken by the robot; thus, they are able to assess sociolinguistic knowledge before grammatical and or linguistic formulation in speech production;

- Pub $6^{\text {th }}$ graders in group B are able to assess grammatical knowledge pertaining to the standard variety by perceiving the missing plural $29 \%$ of the time (see table 4); however, they may not have fully developed sociolinguistic awareness of the fact that plural or zero morphemes are directly related to social context; thus, there is no linkage between grammatical and sociolinguistic knowledge, which necessarily affects the assessment regulated by the strategic component.

It can be argued then that the choice of a particular variety is related to the degree of sociolinguistic proficiency during language production by means of an assessment component that allows the mapping of contextual information, in the light of Bachman (2003 [1990]) and Bachman and Palmer (1996):

Table 6: Possible loci of variation depending on speaker's proficiency of variety use

\begin{tabular}{|c|c|c|c|}
\hline \multirow[t]{2}{*}{$\begin{array}{l}\text { Speakers' } \\
\text { ability to map contextual and } \\
\text { linguistic information }\end{array}$} & $\begin{array}{l}\text { Pre-syntactic } \\
\text { (before grammatical } \\
\text { encoding) }\end{array}$ & Specification of features & $\begin{array}{l}\text { Post-syntactic } \\
\text { (after grammatical } \\
\text { encoding) }\end{array}$ \\
\hline & $\begin{array}{l}\text { message generation } \\
\text { (possible choice of } \\
\text { variety) }\end{array}$ & $\begin{array}{l}\text { morphophonological features } \\
\text { corresponding to varieties }\end{array}$ & $\begin{array}{l}\text { morphophonological } \\
\text { encoding }\end{array}$ \\
\hline Non-proficient & - & $\begin{array}{l} \pm \text { redundant } \\
\text { (underspecified) }\end{array}$ & -s or $-\varnothing$ \\
\hline \multirow[t]{2}{*}{ Proficient } & Standard & $\begin{array}{l}\text { + redundant } \\
\text { (specified) }\end{array}$ & $-s$ \\
\hline & non - standard & $\begin{array}{l} \pm \text { redundant } \\
\text { (underspecified) }\end{array}$ & -s or $-\varnothing$ \\
\hline
\end{tabular}


Notice that the possibility of pre-syntactic choice of variety necessarily depends on the development of the assessment component, which, in turn, depends on the status of the grammatical and sociolinguistic types of knowledge.

In terms of language representation, it is suggested that language use and processing interfere directly on the type of representation a speaker possesses: the morphophonological feature for redundancy in number agreement is underspecified given exposure to variable input, but it can be gradually specified if both sociolinguistic knowledge and strategic competence, more specifically, the assessment component, are sufficiently informed. By combining an assessment component with the idea of declarative knowledge presented by Levelt (1989), it is proposed that teaching and practicing a given form contribute to its incorporation as declarative knowledge, which boosts metalinguistic awareness and, therefore, improves communicative abilities.

The pre-syntactic choice of variety related to awareness of contextual, social and interlocutors' information can be compared to a sort of bilingualism. Bilinguals need to necessarily take into account contextual information in order to inhibit one of the languages so the other can be produced. In the results presented, some $6^{\text {th }}$ graders are able to identify contextual properties and inhibit non-standard forms in order to produce the standard variety.

\subsection{Possible impact on education}

Our results showed that general academic performance as well as SES influence the production of varieties of number agreement in BP. As discussed so far, the impact of schooling is very straightforward: schooling may attenuate the type of SES differences between groups, depending on participant's general academic achievement. Additionally, schooling may mask an ongoing change, as argued by Pires, Rothman and Santos ${ }^{(2011)}$ by rescuing the prescribed standard forms presented in grammar books.

The question that remains is why Pub B $6^{\text {th }}$ graders are not able to reach the same performance as other $6^{\text {th }}$ graders. Such question would require further investigation due to an intersection of factors, such as SES and academic performance. SES per se involves a different range of possible factors such as nutrition, health, safety, home literacy among many other possibilities. Perkins et al. (2013) highlight that SES, home language, home literacy environment, parenting style as well as chronic stress depending on SES influence the development of language and brain. Fernald et al.(2013) show that SES differences in language processing skills and vocabulary emerge from 18 months old: at this age, children from lower SES exhibit lower vocabulary scores and less efficient real-time processing than children from higher SES background. Basit et al. ${ }^{(2015)}$ find differences in preschoolers' production and comprehension according to their SES and highlight the challenge that nurseries and preschools face when preparing children for compulsory schooling. 
Assuming that the assessment of sociocultural and situational aspects of the communicative context is part of the strategic competence and that strategic competence is a set of metacognitive functions responsible to manage grammatical, functional and sociolinguistic information (Bachman, 2003; Bachman \& Palmer, 1996), children can benefit from exposure to diversified communicative situations at school, which are likely to enhance their communicative skills.

Knowledge of language processing and language acquisition may actually help teachers and schools to boost students' communicative skills. Furthermore, the importance of developing oral skills as part of a set of communicative skills in L1 during schooling years should be emphasized as part of teachers' training; this issue has been discussed in the fields of Linguistics and Pedagogy (Bagno \& Rangel, 2005; Kato, 1990; Koch, 2001; Marcuschi, 1997; Negreiros \& Guerra, 2018; Nonato, 2018; Rojo, 2006 among many others) and have been highlighted by the Parâmetros Curriculares Nacionais (see Marcuschi, 2008) and, more recently, by the Base Nacional Comum Curricular (Brasil, 2017a). Its actual execution in language teaching is a matter of research.

\section{Final remarks}

This paper discussed the results of an elicited production experiment on variable number agreement in BP carried out with $6^{\text {th }}$ graders. The results showed that, not only SES, but overall academic performance influences the production of number agreement in BP. It was attested that schooling attenuates the SES differences found during preschool (Jakubów \& Corrêa, 2018), but this effect depends on overall academic achievement. L1 and L2 models of speech production and language proficiency based on communicative skills were brought together to characterize the access to sociolinguistic varieties of number agreement in BP during speech production. It allowed us to suggest that increasing awareness about the use of different varieties of L1 depends on the development of competences prior to grammatical encoding, such as strategic competence that is directly linked to sociolinguistic knowledge. Finally, based on L2 models of language production it was argued that schooling can give rise to a sort of gradual bilingualism in which a variety is chosen prior to grammatical encoding based on an assessment of contextual and social information.

Kasper (1997) states for L2 teaching: "Through awareness-raising activities, students acquire sociopragmatic and pragmalinguistic information [...]"; L1 teaching could also benefit from such an approach.

Thanks to: All those who, to some extent, participated in this research: children, parents, schools, the Secretary of Education of Rio de Janeiro City and the Regional Council of Education of Rio de Janeiro City. 


\section{Notes}

1. This paper is the result of the doctoral research carried out by the first author (doctoral scholarship CNPq 2014 - 2018), under the supervision of the second author at the Pontifical Catholic University of Rio de Janeiro (PUC-Rio), in the development of the research program of the Language Acquisition and Psycholinguistics Lab (LAPAL-PUC-Rio), supported by FAPERJ E-24/202.959/2017 and CNPq 309499/2016.

2. Scherre (1994) proposes that variation of number agreement is already internalized by BP speakers.

3. This research was approved by the Ethics Committee of the Pontifical Catholic University of Rio de Janeiro.

4. The age difference between groups of 6thgraders is due to the fact that, in Pub, some students have failed, at least, one academic year.

\section{References:}

Adger, D., \& Smith, J. (2010). Variation in agreement: A lexical feature-based approach. Lingua, 120(5), 1109-1134. https://doi.org/10.1016/j.lingua.2008.05.007

Almeida, E. M. (2010). Uso e norma: variação da concordância verbal em redações escolares. Tese de doutorado. Universidade Federal do Rio de Janeiro.

Alves, M. T. G., Soares, J. F., \& Xavier, F. P. (2014). Índice Socioeconômico das Escolas de Educação Básica Brasileiras. Ensaio: Aval. Pol. Públ. Educ., 22(84), 671-704.

Bachman, L. F. (2003). A habilidade comunicativa de linguagem (Communicative language ability). Linguagem \& Ensino, 6(1), 77-128.

Bachman, L. F., \& Palmer, A. S. (1996). Language Testing in Practice. Oxford: Oxford University Press.

Bagetti, T., \& Corrêa, L. M. S. (2009). The early recognition of verb affixes: evidence from Portuguese. Proceedings of the 35th Annual Boston University Conference on Language Development.

Bagno, M., \& Rangel, E. D. O. (2005). Tarefas da educação lingüística no Brasil. Revista Brasileira de Linguística Aplicada, 5(1), 63-81. https://doi.org/10.1590/ S1984-63982005000100004

Basit, T. N., Hughes, A., Iqbal, Z., \& Cooper, J. (2015). The influence of socio-economic status and ethnicity on speech and language development. International Journal of Early Years Education, 23(1), 115-133. https://doi.org/10.1080/09669760.2014 .973838

Brandão, S. F. (2011). Concordância nominal em duas variedades do português: convergências e divergências. Veredas, atemática(1), 164-178.

(2013). Patterns of plural agreement within the Noun Phrase. Journal of Portuguese Linguistics, 12(2), 51-100.

(2015). Concordância nominal em três variedades do português: resultados gerais, novas indagações. Cuadernos de La ALFAL, 36-52.

(2016). Concordância Nominal Variável em Português. In J.-P. Chauveau, M. Barbato, \& I. Fernández-Ordóñez (Eds.), Actes du XXVIIe Congrès international de linguistique et de philologie romanes (Nancy, 15-20 juillet 2013). Section 8: Linguistique variationnelle, dialectologie et sociolinguistique. Nancy, ATILF (pp. 41-51). Nancy.

Brasil. (2017a). Base Nacional Comum Curricular. Ministério da Educação, Brasília. 
Brasil. (2017b). Censo Escolar da Educação Básica 2016: Notas Estatísticas. Ministério da Educação, Brasília.

Canale, M., \& Swain, M. (1980). Theoretical Bases of Communicative Approaches to Second Language Teaching and Testing. Applied Linguistics, (1), 1-47.

Castro, A., \& Ferrari-Neto, J. (2007). Um estudo contrastivo do PE e do PB com relação à identificação de informação de número no DP. Letras de Hoje, 42(1), 65-76.

Corrêa, L. M. S. (2009). Bootstrapping language acquisition from a minimalist standpoint: On the identification of phi-features in Brazilian Portuguese. In J. Rothman \& A. Pires (Eds.), Minimalist Inquiries into Child and Adult Language Acquisition: Case Studies across Portuguese(pp. 35-62). Berlin: De Gruyter Mouton

.Corrêa, Letícia M. S., Augusto, M. R. A., \& Ferrari-Neto, J. (2006). The Early Processing of Number Agreement in the DP: Evidence from the Acquisition of Brazilian Portuguese. 30 Th Annual Boston University Conference on Language Development (BUCLD 30). Somervilles, Mass: Cascadilla Press.

Corrêa, L. M. S., \& Name, M. C. L. (2003). Delimitação Perceptual de uma Classe Correspondente à Categoria Funcional D: Evidencias da Aquisição do Português. Fórum Linguistico, 3(1), 55-88.

Færch, C., \& Kasper, G. (1983). Plans and strategies in foreign language communication. In Strategies in Interlanguage Communication (pp. 20-60). London: Longman.

Fernald, A., Marchman, V. A., \& Weisleder, A. (2013). SES differences in language processing skill and vocabulary are evident at 18 months. Developmental Science, 16(2), 234-248. https://doi.org/10.1111/desc.12019

Gomes, C. A., Pontes, M. C., Almeida, M. C., \& Abreu, A. C. (2011). Variação e aquisição da flexão nominal e da flexão verbal. Gragoatá, 30, 39-54.

Grohmann, K. K. (2014). Towards Comparative Bilingualism. Linguistic Approaches to Bilingualism, 4(3), 337-342. https://doi.org/10.1075/lab.4.3.06gro

Jakubów, A. P. S. P., \& Corrêa, L. M. S. (2018). A expressão morfofonológica da concordância de número variável em português brasileiro: uma proposta para a aquisição e a produção infantil. Revista da ABRALIN, 1(45), 47-67. https://doi. org/http://dx.doi.org/10.18309/anp.v1i45.1135

Kasper, G. (1997). Can pragmatic competence be taught? (NetWork \#6) [HTML document]. Honolulu: University of Hawai $>$, Second Language Teaching \& Curriculum Center. Retrieved [January 31, 2019] from the World Wide Web: http://www.nflrc.hawaii.edu/NetWorks/NW06/.

Kato, M. A. (1990). No mundo da escrita: uma perspectiva psicolingüística ( $3^{\mathrm{a}}$ edição). São Paulo: Editora Ática.

Koch, I. V. (2001). A possibilidade de intercâmbio entre Linguística Textual e o ensino de língua materna. Veredas, 5(2), 85-94.

Levelt, W. J. M. (1989). The Speaker as Information Processor. In Speaking: From Intention to Articulation (pp. 1-28). The MIT Press.

(1999). Models of word production. Trends in Cognitive Sciences, 3(6), $223-$ 232. https://doi.org/10.1016/S1364-6613(99)01319-4

Marcuschi, L. A. (1997). Oralidade e escrita. Signótica, (9), 119-145.

Molina, D.S. L. (2018). Aquisição da linguagem e variação linguística: um estudo sobre a flexão verbal variável na aquisição do $P B$. Tese de Doutorado. Universidade Federal de Juiz de Fora. 
Naro, A. J. (1981). The Social and Structural Dimensions of a Syntactic Change. Language, 57(1), 63-98.

Naro, A. J., \& Scherre, M. M. P. (2015). Drifting Toward the Standard Language: A Panel Study of Number Concord in Brazilian Portuguese. In R. T. Cacoullos, N. Dion, \& A. Lapierre (Eds.), Linguistic Variation: confronting fact and theory (p. 356). Routledge.

Negreiros, G., \& Guerra, L. V. (2018). Um estudo sobre a oralidade no livro didático de língua portuguesa. PERcursos Linguísticos, 8(18), 244-260.

Nonato, S. (2018). Processos de legitimação da linguagem oral no ensino de língua portuguesa: panorama histórico e desafios atuais. Cad. Cedes Campinas, 38(105), 222-239. https://doi.org/10.1590/CC0101-32622018183601

Perkins, S. C., Finegood, E. D., \& Swain, J. E. (2013). Poverty and language development: roles of parenting and stress. Innovations in Clinical Neuroscience, 10(4), 10-19.

Pires, A., Rothman, J., \& Santos, A. L. (2011). L1 acquisition across Portuguese dialects: Modular and interdisciplinary interfaces as sources of explanation. Lingua, 121(4), 605-622. https://doi.org/10.1016/j.lingua.2010.06.002

Rojo, R. (2006). As relações entre fala e escrita: mitos e perspectivas - caderno do professor. Belo Horizonte: Ceale (Centro de alfabetização, leitura e escrita) FaE/ UFMG.

Rooryck, J. (1994). On two types of underspecification: Towards a feature theory shared by syntax and phonology. Probus, 6(2-3), 207-234. https://doi.org/10.1515/ prbs.1994.6.2-3.207

Scherre, M. M. P. (1978). A regra de concordância de número no sintagma nominal em português. Pontifícia Universidade Católica do Rio de Janeiro.

. (1991). A concordância de número nos predicativos e nos particípios passivos. Organon, (18), 52-70.

. (1994). Aspectos da concordância de número no português do Brasil. Revista Internacional de Língua Portuguesa (RILP) - Norma e Variação Do Português, 37 49.

Scherre, M. M. P., \& Naro, A. J. (1998). Sobre a concordância de número no português falado do Brasil. In G. Ruffino (Ed.), Dialettologia, geolinguistica, sociolinguistica. (Atti del XXI Congresso Internazionale di Linguistica e Filologia Romanza) (pp. 509-523).

A. J. (2006). Mudança sem mudança: a concordância de número no português brasileiro. Scripta, 9(18), 107-129.

Shafer, V. L., Shucard, D. W., Shucard, J. L., \& Gerken, L. (1998). An Electrophysiological Study of Infants' Sensitivity to the Sound Patterns of English Speech. Journal of Speech, Language, and Hearing Research, 41(4), 874-886. https://doi.org/10.1044/ jslhr.4104.874

Shi, R., Werker, J., \& Cutler, A. (2003). Function Words in Early Speech Perception. Proceedings of the 15th International Congress of Phonetic Sciences, Barcelona 3-9 August 2003, 3009-3012.

Vieira, S. R., \& Brandão, S. F. (2014). Tipologia de regras linguísticas e estatuto das variedades/ línguas: a concordância em português. Lingüística, 30(2), 81-112. 